\section{1. 神経幹細胞移植}

\section{岡山大学神経内科 \\ 阿部 康二}

近年の遺伝子組み換え技術や細胞培養技術の急速な発展に より, 脳梗塞など脳血管障害に対する再生医療の期待が年々 高まってきている，再生医療には遺伝子導入などによる神経 細胞保護療法（脳保護療法）に加えて, 内在性幹細胞活性化 療法,さらには体外からの細胞移植療法が考えられる。再生 医療に関しては，筆者らは既に海馬歯状回（SGZ）や第 3 脳 室下帯 (SVZ) の神経幹細胞が脳虚血後に増殖, 移動しやが て神経細胞やグリア細胞に成熟していくことを報告してい る。また脳虚血後に側脳室注入した神経栄養因子 bFGF およ び EGFにより, 自発増殖再生能を增幅させ臨床症状も劇的に 改善したとされる。.さらに様々な幹細胞を脳梗塞病巣に移植 することによる再生治療によって, 脳梗塞病巣の縮小や臨床 症状の改善の報告が相次いでおり, 今後の発展が期待されて いる.

\section{2. 内在性神経幹細胞を用いた神経再生療法の現状 と展望}

東京大学脳神経外科

川原 信隆

神経疾患に対する新たな治療として，移植や再生に基づく 機能再建療法が注目されてきている。特に近年は, 内在性自 己神経幹（前駆）細胞を直接賦活して機能再建を行う治療法 が新たに提唱されている. 移植治療に比較して, 免疫抑制, 倫理，供給源の問題などは少ないが，これらの幹細胞の存在 は脳内でも限局しており，すべての部位への応用が可能か否 かなどの問題点を含んでいる. 我々が㸷苗類の虚血性神経細 胞死後の再生を検討したところ, 海馬 CA1 領域においては成 長因子を脳室内に短期間投与して, 内在性幹細胞を賦活化す ることで，40\%の細胞の再生を得ることが示された。これら の細胞は電気生理学的にも個体レベルでの行動解析にても, 機能の回復に寄与していることも判かった. 他の選択的神経 細胞死モデルのいくつかでも, 同様の神経再生が生じること が示されており, 成体脳が驚くべき自己複製機構を保持して いることを示している。人間の脳でもこれらの神経幹細胞が 広範囲に存在することが判明しており, 慢性の変性疾患も含 めた広範な疾患への応用が期待される。

\section{3. 霊長類 ES 細胞からのドーパミン産生神経誘導と 霊長類モデルへの移植後の解析}

京都大学脳神経外科

高橋 淳, 高木 康志, 橋本 信夫

パーキンソン病に対する細胞移植療法のひとつとして ES 細胞を用いた方法が挙げられる。我々は骨髄由来のフィー ダー細胞上で ES 細胞を培養するという方法 (stromal cellderived inducing activity； SDIA 法）を用いてドーパミン産生 神経の誘導, 移植を行っている. 幹細胞移植臨床応用のプレ 臨床研究として, 以下の実験を行った。まずカニクイザル ES 細胞から神経幹細胞を誘導し,さらに FGF2 と FGF20 を作用 させることによってドーパミン産生神経の誘導効率を高め た. MPTP 静脈内反復投与によってカニクイザルパーキンソ ン病モデルを作製。その線状体に ES 細胞由来のドーパミン 産生神経を移植し, 神経症状の変化をスコア化して観察した。 移植後約 3 力月で神経症状の改善がみられ，PETによって F-dopa の取り込み上昇, すなわち, 移植細胞がドーパミン産 生神経として機能していることが確認された，腫瘍形成はみ られなかった。これらの結果は ES 細胞移植臨床応用の可能 性を支持するが,ささらなる効果と安全性の評価が必要である。

\section{4. 中枢神経系における再生医療の進歩一骨䯣細胞 を用いて}

$$
\text { 札幌医科大学脳神経外科 }
$$

神経再生医療におけるドナー細胞の確保は，必ずしも容易 なことではない，期待される治療効果, 副作用, 感染症, 免 疫拒絶反応, 倫理問題, 細胞供給体制, 社会事情, 実現の可 能性をトータルでバランスよく検討し最良の選択をすること が必要である，骨髄中に存在する細胞をドナー細胞として使 用する場合, 自分の細胞を使うことができるので, 感染症, 免疫拒絶反応, 倫理面での諸問題がない. また, 大きな利点 として, 脳神経の損傷した部位への直接移植のほか, 静脈内 投与でも高い治療効果が期待できることである. 静脈内に投 与された骨髄細胞は, 脳損傷の部位に到達して神経保護作用 を発揮すると同時に，自らも神経系細胞になって再生治療効 果を発揮すると考えられている，骨髄移植は，既に白血病の 治療などで行われている治療であり, 安全かつ非侵襲的に十 分量のドナー細胞が確保できることが判明している，近い将 来, 自分自身の一部を“自己骨髄幹細胞バンク”などに蓄え ておくことで, 将来の病気に備える時代が来るかもしれない. 